\title{
"I'll Rise": Rememory, Hope and the Creation of a New Public Sphere in Ben Harper's Music
}

\author{
Delphine Gras \\ University of Washington
}

Recent studies about resistance music in the United States primarily focus on the hip-hop movement. However, it does not offer the only musical discourse contesting contemporary injustices. Even though the debate about hip-hop is a crucial one that deserves full attention, it seems necessary to widen the current conversation on music to take into account a wider array of musical genres and artists. This will in turn allow us to see the revolutionary power of music in its full force. In the United States, black music, from the Spirituals to Rhythm and Blues, has undeniably been a potent agent for social change. Because they enable strangers to identify with each other through a common discourse, songs from many different genres have fostered what Benedict Anderson calls "imagined communities."

As a starting point to this invitation for further studies on contemporary music as a powerful counter-discourse, I will be looking at Ben Harper, in order to see how he upholds the social power of music and promotes diversity. With Martin Luther King Jr. and Bob Marley for inspiration, Ben Harper is one of the many artists who pursue the fight for a more egalitarian society, while at the same time refusing labels. Exploring a variety of genres, he seeks to express his diverse origins, thus debunking classifying systems like census or musical categories. Indeed, his paternal grand-mother is half Cherokee, half African-American, while his maternal great-grand-mother is of RussianJewish descent. Harper celebrates a variety of influences: from black diasporic music to the many musical American traditions. His refusal of categories and his powerful discourse offer a means to expand the contemporary public sphere.

This project explores the role of Ben Harper's music in the fostering of a more inclusive public sphere. "I'll Rise" refers both to Maya Angelou's poem and to the song Harper created in her honor. This song is central to our discussion as it inscribes Ben 
Harper in the tradition that precedes him-a tradition all the richer as it does not limit itself to the field of music. Moreover, the artist he pays tribute to is not only a woman, but a feminist, which hints at Harper's openness. Finally, "l'll Rise" evokes the main topics of this study: the hope to overcome any hardship, the will to free oneself from alienation and oppression, and the desire to assert one's worth. After defining the possibility to foster a public sphere through music, this study will analyze the work of Ben Harper around three themes: rememory and tradition, hope and freedom, and the creation of a larger public sphere.

Jürgen Habermas's The Structural Transformation of the Public Sphere: An Inquiry into a Category of Bourgeois Society cogently delineates the power of the public sphere as a social agent. Indeed, as Gwendolyn Pough claims: "Habermas's model is relevant and useful because it sets up as a model a time when individuals came together, discussed issues of collective good, worked toward change, and challenged state power" (Pough 2004, 16). Habermas's main appeal stems from the fact that his concept of the public sphere gives back agency to individuals. He offers an alternative to Marxist determinism so that social entities may have the potential to change their living conditions. Habermas, like Benedict Anderson in Imagined Communities, shows that Marx's study of the pervasiveness of capital, all-powerful economic structures and ideology does not account for the disruptive presence of the media or the potential of social imaginaries to challenge order and transform society.

Diverse groups have asserted their will to take control of their destinies and have indeed altered state apparatuses on several occasions. The bourgeois class's overthrow of the nobility set the example. Habermas demonstrates how the bourgeois class gained political power over the State thanks to its growing public sphere. It is important to note that he makes it clear that this uprising deeply relied on the increasing use of the media. The press widely spread and undermined the authority of the State in order to advance an alternative agenda. As these new ideas disseminated through the mass media, the press influenced the population at large.

But, Habermas's title immediately betrays the narrowness of his study. Its sole focus is the bourgeoisie. Vorris Nunley rightfully points to the fact that many have discarded his theory because of its special focus on the bourgeoisie. Many theorists agree that Habermas presents a restricted version of the public sphere that does not account for differences. He describes a highly normative and prescriptive public sphere that solely belongs to a wealthy class. Hence, he does not allow for much counterdiscourse, let alone coming from disenfranchised others. His analysis appears even more problematic now that the bourgeois class also represents the power of the State. However, rather than rejecting his thesis altogether, reshaping it seems more productive.

While Habermas has redefined his analysis of the public sphere to announce its decline and 'refeudalization' in "The Public Sphere: An Encyclopedia Article," I would like to suggest that the means to create open public spheres have evolved rather than disappeared. Everybody can daily challenge the imposition of language from the outside, slowly shaping their own discourse and progressively drifting away from alienating ideology. 
Through a more extensive study, we soon realize that popular music emerges as a major tool for diverse public spheres, an extremely potent social agent that reaches across class. Popular music is capable of creating new meaning, thus reshaping language and the public arena, as the press did for the bourgeois class. It thus enables strangers to identify to a common discourse and has the potential to transform society, mainly for groups silenced by hegemonic powers. It is therefore not surprising that many artists aspire to liberate themselves and others through emancipatory musical discourse.

While the bourgeois class enjoys its monopoly over the power of naming, everyone individualizes language. As a consequence we are not locked within the ideology of the language we express ourselves in. As Salman Rushdie demonstrates in "Imaginary Homelands" language shapes our epistemology-our ay of apprehending the world-but we can transform it as well. Our constant interactions foment new meanings so that language is never fixed. It can always evolve, hence allowing us to call into question set rules and phrasings. In the specific African American rhetorical tradition this phenomenon corresponds to "Nommo, the African belief in the pervasive, mystical, transformative, even life-giving power of the Word" (Gilyard 2004, 12). Here, the editors of The Voice of Black Rhetoric echo a point of view similar to Cornelius Castoriadis's concept of "magma," a fluid composition of dialogical forces recurrently renewing itself. As Castoriadis asserts: "the social is this very thing- self-alteration" (Castoriadis 1987, 215).

In the song "Walk Away" (1992), Harper exemplifies how we can all transform language. He makes full use of his poetic freedom and creates many puns to reinforce the theme of the lost love:

\section{But you put the happy \\ In my ness \\ You put the good times \\ Into my fun.}

Breaking down the word "happiness" in two ("happy" and "ness"), he reinforces the feeling of loss and separation. Indeed, while "happy" is a word in and of itself, "ness" loses any meaning. This loss of signification hints at the feeling of the abandoned person of the song. For him, life has lost its meaning because of a break-up. In this stanza, Harper invents a word ("ness") to more potently express the sadness of the separation, as well as the feeling of happiness and completeness that preceded it. "Walk Away" thus constitutes a great example of how songs can modify language, thus shaping what Castoriadis calls "magma" and illustrating the power of "nommo." This concept of nommo reappears throughout Harper's work. As we will see, "Excuse Me Mister" fully demonstrates how individuals can reclaim their power of naming and contest accepted norms.

Change stems from the confrontation and fusion of multiple forces and discourses. The public sphere cannot be oblivious of the plurality of its participants. Similarly, the public sphere does not circulate its ideas solely through the press. It uses a variety of media, "micro-narratives of film, television, music, and other expressive forms, which allow modernity to be rewritten more as vernacular globalization and less as a concession to large-scale national and international policies" (Appadurai 1996, 10). 
"The vernacular" matters as a means to oppose the normative discourse of the State, now part of the bourgeois public sphere. Hence, Arjun Appadurai posits that multiplicity is the key to counteract a master-narrative. If we locate counter-hegemonic discourse in a specific place, it might not be effective in destabilizing bourgeois order. On the contrary, highlighting and praising a variety of discourses debunks the bourgeois public sphere for its lack of perspective and inclusiveness. As a consequence, it is also necessary to resort to a variety of media, even more so as the bourgeoisie still regulates a fair part of the Press. A more inclusive public sphere must consist of "micronarratives" from different perspectives, through different media.

Music constitutes one of these "micronarratives" and emerges as a more popular mode of expression than the press. Concerts, popular gatherings where music spreads its influence, therefore take part in the praxis that allows strangers to unite. The members of the audience respond to a common discourse. As they actively share a moment, they have access to a collective epistemology that often contrasts with State or bourgeois ideology.

Looking at Harper's concerts allow us to see how he reclaims his own tradition and values, opposing bourgeois order. He brings people together to form a counterpublic. For the time of song or with a lasting impact, his discourse is shared and opens up the public sphere. As a rallying cry, he often concludes his concert with "Like a King" that then merges with "I'll Rise." This last song, "I'll Rise" not only concludes his concerts, but also his second album. While the title of this album, Welcome to the Cruel World, announces a pessimist attitude, Harper chooses to end with a message of resolution and resistance. The a cappella form makes his message even stronger as it situates the lyrics closer to daily reality and talk. When Harper sings this set of two songs in a concert, he inscribes himself in the struggle for social equality while paying tribute to Maya Angelou, Martin Luther King Jr. and Rodney King. He even invokes the longer traditions of African-American artists when he echoes the word of the famous guitarist Blind Willie Johnson at the end of "Like a King."

The last lyrics he incorporates in his finale are Bob Marley's "don't give up the fight." This moment marks the apex of his call for change as he draws inspiration from previous generations. On May $13^{\text {th }} 1994$ at the Fillmore Theater in San Francisco Harper even included Marley's lyrics from the song "Get up, stand up." This message is all the stronger as it constitutes the last words of the concert. Harper declares:

I often end my concerts with this song because it works really well at that moment. This song symbolizes uprising. A revolt of the mind, a force, a comprehension. Refusing to submit to anyone. An aspiration to something better in life. The greatest of blessings is a shared blessing. It's a song about liberty.

At this moment, the crowd overcomes class, gender or national categories. They unite their hope, their Will to Live to Fight for [Their] Mind, to borrow two of Harper's album titles. Fists up in the air as a sign of their participation in the fight, they physically pay tribute to Marley and the quest he had. Like Marley, Harper believes that music can bring people together. 
Concerts secularize the religious sentiment in order to unite diverse individuals, an additional step towards a more inclusive public sphere.

The cheering crowd at a rock festival is similarly fused. There is a heightened excitement at these moments of fusion, reminiscent of Carnival or of some of the great collective rituals of earlier days. So much so that some have seen these moments as amongst the new form of religion in our world. Durkheim gave an important place to these times of collective effervescence as founding elements of society and the sacred. (Taylor 2004, 169)

As it establishes a comparison between concerts and carnival, this analysis brings to mind Mikhail Bakhtin's study of the carnivalesque. For Bakhtin, "carnival" represents a charivari, a day celebrating diversity. It does not constitute a simple reversal of order. Instead, all barriers break down, undermining more profoundly any categorization. Art is part of Castoriadis's "magma." The lexical fields of "fusion" and "effervescence" are indeed highly reminiscent of his analysis. Music constitutes a powerful discourse and affects our epistemologies. In the dialogue it operates with hegemonic discourse it can have unpredictable effects, eruptions that destabilize order. Whereas it is not totally clear if carnival allows for a lasting alteration or constitutes a cathartic moment before order reaffirms itself, Castoriadis's magma is always changing. It is never cast in one shape because it is made of a wide range of discourses and social interactions. Multiple voices, multiple media, and multiple audiences compellingly complicate Habermas's public sphere.

There is not one but many public spheres. The owners of the press are not the only ones capable of creating imagined communities. As Neal claims:

Thus the use and critique of mass media and popular culture can serve as a viable mode of social and political praxis for the post-soul intelligentsia, as they seek to liberate dated tropes and stereotypes of blackness in ways that venture to decolonize contemporary African-American thought processes. (Neal 2002, 122-123)

Music plays a tremendous role in the building of a community and represents a potent agent for social change and the democratization of the public sphere. It expresses communal values and facilitates a sense of belonging.

I will focus on Black music because it has not only expressed or mirrored the oppression and hopes of African Americans, but it has also enabled the latter to assent their humanity and, hence, to gain cultural and political representation. Music enables one to constitute a specific public sphere free from the alienating influence of the State as we can see from Vorris Nunley's statement: "Countless known and unknown Black bards temporarily escaped the hegemonic gaze of Whiteness to make themselves a world" (Nunley 2004, 223). As it was the case in the past, the bard is at the center of the community. Through his composition he unites strangers under a common social imaginary. Music can also keep memories alive or restore forgotten events. By keeping traditions alive and mentioning silenced events, it constitutes a compelling counterdiscourse. The role of the griot in the black diaspora illuminates this aspect of music. As a communal singer, he voices the values and praises the greatness of his group. Hence 
music shapes the identity and distinctness of a community. It fosters a sense of solidarity.

The griot unites the community with a collective discourse that is greatly imbued with social and political content. $\mathrm{He}$ is also an historian who keeps the traditions alive and constantly celebrates past events that hegemonic powers would otherwise silence. The griot thus plays a major role in maintaining an alternative collective memory. This in itself constitutes a counter-discourse because it offers a perspective different from the one of the bourgeois public sphere. The griots rewrite historical accounts that had left them out. In To Wake the Nations, Eric Sundquist elaborately demonstrates that these singers are both spirituals leaders and rebels. Their subversive songs give an impetus for action and emancipation so that they serve as epistemological disruptions in white patriarchal American discourse.

In this context, it is interesting to see recent African American artists presenting themselves as griots. Greg Tate indeed mentions a band named "The Six Legged Griot Trio," while Gwendolyn Pough establishes a parallel between hip-hop singers and griots. Throughout different musical periods African American musicians have created a language of their own, shaped their epistemology and claimed their power of naming, thus shaping their own reality and community. This epistemic challenge constitutes a form of nationalism that clearly aims at changing society.

Songs, which Dipesh Chakrabarty identifies as belonging to "forms of nationalist mobilization" (Chakrabarty 2000, 39) offer a call for action. In the nineteenth century, the slaves organized uprisings thanks to the hope and coded messages of the spirituals while African Americans overcame the Reconstruction and the Depression eras thanks to the call for change of the Blues and the Jazz. In the sixties, Martin Luther King Jr. even claimed that music was the strongest weapon against injustice, and mobilized many specifically thanks to that medium. As Arjun Appadurai powerfully asserts: "The imagination is today a staging ground for action, and not only for escape" (Appadurai 1996, 7).

Nowadays, Rap artists represent the group that most visibly voice its discontent, or even rage, in order to oppose the normative bourgeois public sphere. Following the steps of their predecessors, they use music to uphold memory and shape a new life for themselves: "They are the griots of the ancestral land speaking into the rhetoric of the future" (Cook 2004, 269). They undeniably create a sense of public space. As a consequence, a large part of the youth identifies with them. It is therefore not surprising that Mark A. Neal celebrates their rhetoric. He demonstrates how hip-hop discourse expands the black public sphere and allows for a high degree of democratization of the latter.

As Tricia Rose cogently remarks, "Given the complexity in rap's storytelling, how is it that most Americans only know about the most extremely violent passages?" (Rose 1994, 156). She denounces the demonization of Hip-Hop, pointing to the fact that white bourgeois public sphere purposely turns these artists into scapegoats in order to undermine their discourse. Her most cogent analysis demonstrates how it is much easier to blame violence on the vehemence of their prose rather than attempting to change the conditions that foment injustices and the alienating institutions that have actually favored racism and sexism for centuries. However, most critics focus on the 
fact that "black males cultivated and embraced the hypermasculine image" (hooks 1994, 131), again failing to see that it emerges as a means to cope with and counteract their feminization and reification by white bourgeois society.

The contemporary despair that permeates a considerable part of rap music is more problematic. While rap music urges to resist and potently counteracts hegemonic discourse, it sometimes fails to offer many exit doors or constructive ways to oppose oppression. In these cases, it typifies contemporary despair and post-structuralist cynicism, which explains why Kalí Tal mentions the "decline of Black counterpublic" (Tal 2004, 40). People are too depressed to act. One may wonder whether the commodification of music has anesthetized musicians and deprived them of their potential as major initiators of social change.

How can African American males express themselves through music and move people to action in the twenty-first century? This endeavor is not only one to find one's adequate expression but also one to delineate one's identity as both an individual and a member of a larger group. In a stiflingly categorizing and labeling society the question arises of how an artist can express himself or herself freely. The solution stems from the fact that one does not solely belong to one group but many. Diversity and tradition do not have to oppose each other in an either/ or logic of Hegelian dialectics.

Ben Harper figures as one of the contemporary musicians that offer a powerful discourse against oppression, while still providing hope in a manner reminiscent of the long tradition of the artists of Spirituals, Jazz, Blues, Rhythm and Blues, or Soul. His music incorporates and expands the potential of rap music thanks to its inherent diversity and unflinching resistance to classification. Harper thus embodies the "connection between violence an idealism" that Chakrabarty mentions (Chakrabarty 2000 , 45), uniting the philosophy of Martin Luther King and Malcom X, two philosophies that never really were split and which have always been co-dependent. Indeed, in an interview Harper declares:

I could spend all of my time singing about hatred, condemning gangs, machismo, violence and it wouldn't change anything. So I sing about love. Even 'Like a King,' my song about Rodney King is a song about love, with a soft, non-violent chorus. It's not a call to hatred.

He pays tribute to Martin Luther King Jr. in "Like a King" (1992), his song about the 1992 Los Angeles riots. Here he condemns the persistence of racial discrimination and violence: "Well Martin's dream/ Has become Rodney's worst/ Nightmare." Martin Luther King Jr.'s dream of peace and tolerance has not been achieved yet because racism still subsists in the United States. However, this song does not lack optimism as Ben Harper explains:

The most amazing thing about Martin Luther King was that he exuded peace, it emanated from him, from his whole being, from his slightest look, his slightest gesture. When you're in that place, you can move forward. He's THE man, one of the most nonviolent people the world has ever seen; everything was prayer for him, and that's exactly the road we have to take. 
Racial tensions can only disappear if we follow King's path. For Harper, King is indubitably seen as a model and a king, as we can notice from the repetition of "like a king" throughout that song. Hence, Harper draws strength from his predecessor in order to demonstrate that hope is resistance.

Hope and Faith constitute two major elements of musical expression. In the African American tradition they represent the mainstays of musical creativity as well as key elements African Americans must deploy in order to overcome past and present ordeals. While a good share of the African American population would like to forget the atrocities of slavery, many theorists, including bell hooks and Toni Morrison, posit the need to acknowledge past hardships so as to prevent similar situations from arising anew, to correct an erroneous and romanticized account of history, and to proudly assert their Will To Live, to use the title of Ben Harper's fourth album.

Ben Harper's recourse to forms and tropes alluding to Spirituals inscribes him in the larger tradition of music as protest and survival. Nowadays, the term "survival" may seem overstated but it hints at the survival of a tradition as well as the survival of the will to make a better world. What many fail to see is that hope is itself a form of resistance. With songs like "Two Hands of a Prayer" (1999) and "In the Lord's Arms" (1999), Ben Harper revives the tradition of Gospel and the Spirituals as providers of hope in the future to come. He thus provides a good example of counter-discourse to contemporary nihilism as defined by Herbert Hill and Neil Nehring.

"Power of the Gospel" (1995) stands out as the epitome of his many tributes to the spirituals, not only due to its undeniable artistry, but because it conflates most tropes of the Spirituals. The long introduction, in which wind instruments prevail, creates a very emotional opening. Its multitude of tonalities and its contrapuntal structure seem to echo different voices, reminiscent of a eulogy, hence restoring forgotten songs and paying tribute to the deceased in a musical process of "rememory." For a while the music stops and the wind instruments disappear so that we can only hear the acoustic guitar. Finally, there is a pause before the words and the wind instruments break through and shatter the silence to resonate so that we listen to the first words of this chiasmic subversive message referring to the power of the Gospel: "It will make a weak man mighty/ It will make a mighty man fall." Not only do those two lines express hope but they also employ the same ambiguity as the one found in the Spirituals. The message of hope empowers the oppressed while it also refers to a reversal of the situation, hence constituting a possible call for uprisings thanks to its inherent polysemy. Through his music Ben Harper insufflates a new breath, while celebrating traditions with many tributes to the Spirituals, the Blues, or any preceding style. When he celebrates "The Power of the Gospel," what he mainly praises is hope, as well as the tradition in which he inscribes himself, the musical tradition of resistance.

While Ben Harper echoes Robert Johnson's Blues of loneliness ("Crossroad Blues") in songs like "Church House Steps," he also echoes the determination present both in the Spirituals and in the Blues, not to fear death in songs such as "Glory and Consequence" (1997) or in the shadow song of the same album "Bye and Bye, I'm going to see the King," which pays tribute to Blind Willie Johnson. Moreover, Ben Harper revitalizes the conceit of the road in songs like "How many Miles Must We March" (1992) "One Road to Freedom" (1995) or "Picture of Jesus" (2002). The road metaphor often appeared in the Blues. It anchored songs in reality, while evoking hope 
in spite of obstacles. "How many Miles Must We March" echoes Robert Johnson's "Stones in my Passway": "I got stones in my passway/ And my road seem dark as night [...] Boys, please don't block my road." He asserts his determination. He will go on regardless of what he has to overcome. The road to social equality is long and troublesome. But these artists decided to bring their own contributions to the fight thanks to their songs.

When Ben Harper sings "Excuse Me Mister" (1995), he attacks politicians for their detached and blind attitude. The dehumanized voice prefigures the dehumanizing conditions that a ruling minority imposes on others, which is emphasized by musical breaks. These pauses seem to stop time so as to point to the seriousness of the message while also celebrating specific African rhythmic traditions. Screams and back vocals echoing the wider society enhance the urgency of the situation. However, he does not present himself as a victim. On the contrary, he proudly asserts agency with the repetition of "I'm a Mister too." This song deconstructs the hegemony of white capitalist patriarchy by appropriating its power of naming. Indeed, taking the title "mister" out from the front of the politicians' names, Harper symbolically deprives them of their authority so that he can denounce their exclusivist attitude and expand the title "mister" to the wider community which should be included in the distribution of resources.

In what Andrew Ross describes as an increasingly disenchanted generation in "The Gangsta and the Diva," music becomes the most potent locus of resistance because youth do not believe in politics any longer. Ben Harper can be compared to rappers who "do bring issues and concerns, via their lyrics, to public attention that might not otherwise be heard" (Pough 2004, 29). What makes his music so interesting is that it is both vehement and hopeful: "I'm not a negative cat,' Harper contends. 'I've been far more militant in my life and it hasn't gotten me anywhere. But I'm down for expressing negativity to get to a positive place'" (Rolling Stones, September 16, 1999). His criticism is constructive and his involvement with the community is diverse.

He mostly provides a safe place for women and does not solely endorse a hypermasculine heterosexual perspective. He actually demonstrates a certain openness and desire to comment on gender and sexuality. Moreover, he seems to be in touch with his feelings and dares revealing weaknesses, echoing Rose's perspective about emotions: "We learn a great deal about ourselves in spaces of emotional vulnerability" (Rose 1994, 155). Although Harper replicates some paradigms of sexist Blues lyrics when he depicts women as treacherous, he also impersonates women to voice their everyday ordeals. In the song "Mama's got a Girlfriend Now" (1992) he transcends what could be called the appropriation of the female voice and body to condemn the attitudes of passive violent men and celebrates nurturing homosexual love. We can see that the homosexual relationship he positively depicts contrasts with the heterosexual one he discards in the same song or in "Widow of a Living Man" (1997), here again voicing women's sorrows and sense of loneliness.

Ben Harper acknowledges the necessity to be humble when speaking for others and mentions his upbringing by women. As already mentioned, he pairs his criticism of women with their celebration. He does not compartmentalize them as victims and offers a wide range of portrayals. He mentions their talking in tongues "In the Lord's Arms" (1999), while in "Gold to Me" (1995) he depicts them in an extremely positive light. While criticizing materialism and superficiality of the larger society, he contrasts inner 
riches with temporary superficial attributes of wealth. Instead, he praises human beauty, "not the kind of gold that you wear." Similarly, "Diamond on the inside" (2002) pays tribute to the beauty of women and the beauty of African American communities. While "Ground On Down" (1995), "Ashes" (1997) and "Glory and Consequences" (1997) express the fear of losing the loved one, which was a permanent threat during slavery, "Burn To Shine" (1999) and "Forever" (1992) reverse the negative portrayals of split families to promote a positive image of families in black communities.

Moreover, his diverse incursions in many musical genres mirror his refusal to stifle people's identity within labels: "As he has throughout his career, Harper showed no regard for musical boundaries" (Marie Elise St. Léger 1999). Throughout his career, he has repeatedly asserted his refusal of categories. The revolutionary potential of his music is heightened by his attempt to disregard delimitations between musical genres. This decision echoes the concerns of many critics to provide a safe black public sphere that would accept and value its diverse constituents. It is precisely because Ben Harper's musical influences are varied that his compositions offer a wide public sphere. Like Stevie Wonder he explores a wide array of styles-the Spirituals, Gospel, Blues, Rhythm and Blues, Rock and Roll, Reggae, Rap music, or Heavy Metal. This impressive assortment undeniably expresses a rare openness. It is important to note that Stevie Wonder was not a cross-over. As Arnold Shaw emphasizes, Wonder took position on several issues. Similarly he claims that "The sound of popular music in America until the advent of Rock'n'Roll was forged by three black singers-Ethel Waters, Louis Armstrong, and Billie Holiday. All three are regarded as Jazz and Blues singers, but all three sang the Pop songs of their days" (Shaw 1986, 272).

Some styles reflect their content better than others. Hence, Harper's incursion in Heavy Metal might stem from a desire to follow Jimi Hendrix's longing for revolution. The latter indeed said "'Maybe if we play loudly enough,' he said, 'we can shut out the world"' (Shaw 1986, 243). Harper touches on every style, allowing the style to mirror the message of his songs. His incursions into a plethora of musical influences appear as a sign of open-mindedness and richness instead of constituting the badge of a crossover and commercial product. In an interview, he claimed that living in a fragmented world induced him to think that every blending was possible. As such his explorations into country music or other styles that are often associated with "white culture" do not point to a crossover or an attempt to pass, but a conscious effort to mirror and express a desire for both unity and for the respect of differences.

It is precisely because of his refusal of stifling categories and his hopeful but critical portrayal of contemporary American society that Ben Harper contributes to the elaboration of a contestatory discourse, thus opening doors towards an heterogeneous public sphere. He is one of the most promising contemporary artists using music as a weapon. In his compositions he follows the path of Bob Marley and stands against social injustices, while attempting to foster hope as many artists did before through the Spirituals, Jazz, Blues, Rhythm and Blues, or Soul. His songs uphold memories while offering the possibility for a more egalitarian future. What he really offers is a refusal of stifling labeling, a door to a diverse public sphere, not a white bourgeois public sphere, not a black patriarchal public sphere, but an all-encompassing public sphere united by a popular form-music. This analysis is but a stepping stone for further debates on the revolutionary role of music in contemporary society. It merely constitutes one of the many examples that demonstrate that the death of Rhythm and Blues and the tradition 
of music of resistance has not yet come. As Ross powerfully advocated: "Let this be a starting point, and not a conclusion, for cultural politics of masculinity that is willing to take diversity as a radical task, and not as a liberal, consensual limit to intolerance" (Ross 994, 166).

\section{References}

Anderson, Benedict. 1991. Imagined Communities. New York: Verso.

Appadurai, Arjun. 1996. Modernity at Large. Minneapolis: University of Minnesota Press.

Banks, Adam J. 2004. Looking forward to look back: technology access and transformation in African American rhetoric. In African American Rhetoric(s): Interdisciplinary Perspectives, ed. Elaine B. Richardson and Ronald L. Jackson, 189203. Carbondale: Southern Illinois University Press.

Calhoun, Craig. 1992. Introduction to Habermas and the Public Sphere, ed. Craig Calhoun, 1-48. Cambridge, MA: MIT Press.

Castoriadis, Cornelius. 1997. "The only way to find out if you can swim is to get into the Water": introductory interview. In The Castoriadis Reader, ed. David Ames Curtis, 1-34. Oxford: Blackwell.

— 1987. The Imaginary Institution of Society. Cambridge: MIT Press.

Chakrabarty, Dipesh. 2000. Postcoloniality and the artifice of history. In Provincializing Europe: Postcolonial Thought and Historical Difference. 27-46. Princeton: Princeton UP.

Cook, William W. 2004. Found not founded. In African American Rhetoric(s): Interdisciplinary Perspectives, ed. Elaine B. Richardson and Ronald L. Jackson, 259272. Carbondale: Southern Illinois University Press.

Du Bois, W.E.B. [1903] 1973. The Souls of Black Folk. Millwood: Kraus-Thomson Organization Ltd.

Gaonkar, Dilip. 2002. Toward new imaginaries: an introduction. Public Culture 14.1: 119.

Ghesquière, Gaëlle. 2004. Ben Harper en Live. Paris: Flammarion.

Gilyard, Keith. 2004. Introduction to African American Rhetoric(s): Interdisciplinary Perspectives, ed. Elaine B. Richardson and Ronald L. Jackson, 1-20. Carbondale: Southern Illinois University Press.

Golden, Thelma. 1994. My brother. In Black Male: Representations of Masculinity in Contemporary American Art, ed. Thelma Golden, 19-43. New York: Harry N. Abrams, Inc. 
Habermas, Jürgen. 2006. The public sphere: an encyclopedia article. In Media and Cultural Studies: Key Works, ed. Durham Meenakskigigi and Douglas M. Kellner, 72-77. Malden: Blackwell.

1991. The Structural Transformation of the Public Sphere: An Inquiry into a Category of Bourgeois Society. Trans. Thomas Burger with the assistance of Frederick Lawrence. Cambridge: MIT Press.

Holsey, Steve. 1994. What would Martin Luther King Jr. say to a group of 'gangsta' rappers?" Michigan Chronicle, January 19, A1.

hooks, bell. 1994. Feminism inside: toward a black body politic. In Black Male: Representations of Masculinity in Contemporary American Art, ed. Thelma Golden, 127140. New York: Harry N. Abrams, Inc.

Kofsky, Frank. 1970. Black Nationalism and the Revolution in Music. New York: Pathfinder Press.

Latour, Alexandre. 2003. Ben Harper de A à Z. Paris: Prélude et Fugue.

Muhammad, Askia. 1996. Dr. Martin Luther King, Jr. and jazz. Sacramento Observer, January $17, \mathrm{C} 1$.

Naranch, Laurie E. 2002. The imaginary and a political quest for freedom. Differences 13.3: 64-82.

Nunley, Vorris L. 2004. From the harbor to da academic hood: Hush Harbors and an African American rhetorical tradition. In African American Rhetoric(s): Interdisciplinary Perspectives, ed. Elaine B. Richardson and Ronald L. Jackson, 221-241. Carbondale: Southern Illinois University Press.

Neal, Mark Anthony. 1999. What The Music Said: Black Popular Music and Black Public Culture. New York: Routledge.

2002. Soul Babies: Black Popular Culture and the Post-soul Aesthetic. New York: Routledge.

Parker, Andrew, Russo, Mary, Sommer, Doris, and Yaeger, Patricia, ed. Introduction to Nationalisms and Sexualities, ed. Parker, Andrew, Russo, Mary, Sommer, Doris, and Yaeger, Patricia, 1-17. New York: Routledge.

Pough, Gwendolyn D. 2004. Check It While I Wreck It: Black Womanhood, Hip-Hop Culture, and the Public Sphere. Boston: Northeastern University Press.

Richardson, Elaine B. and Jackson, Ronald L. 2004. Preface to African American Rhetoric(s): Interdisciplinary Perspectives, ed. Elaine B. Richardson and Ronald L. Jackson Carbondale: Southern Illinois University Press.

Rose, Tricia.1994. Rap music and the demonization of young black males. In Black Male: Representations of Masculinity in Contemporary American Art, ed. Thelma Golden, 149-158. New York: Harry N. Abrams, Inc. 
Ross, Andrew. 1994. The gangsta and the diva. In Black Male: Representations of Masculinity in Contemporary American Art, ed. Thelma Golden, 159-166. New York: Harry N. Abrams, Inc.

Rushdie, Salman. 1991. Imaginary homelands. In Imaginary Homelands: Essays and Criticism, 1981-1991, ed. Salman Rushdie, 9-21. London: Granta Books 1991.

Shaw, Arnold. 1986. Black Popular Music in America: from the Spirituals, Minstrels, and Ragtime to Soul, Disco, and Hip-Hop. New York: Schirmer Books.

Tal, Kali. 2004. From panther to monster: representations of resistance from the Black Power Movement of the 1960s to the boyz in the hood and beyond. In African American Rhetoric(s): Interdisciplinary Perspectives, ed. Elaine B. Richardson and Ronald L. Jackson, 37-58. Carbondale: Southern Illinois University Press.

Tate, Greg. 1994. He is truly free who is free from the need to be free: a survey and consideration of black male genius. In Black Male: Representations of Masculinity in Contemporary American Art, ed. Thelma Golden, 111-118. New York: Harry N. Abrams, Inc.,

Taylor, Charles. 1990. Modes of civil society. Public Culture 3.1: 9-132.

2004. Modern Social Imaginary. Durham: Duke University Press. 